\title{
Arab Spring in Morocco: social media and the 20 February movement
}

\author{
Lenie Brouwer, Edien Bartels \\ VU University, The Netherlands
}

\begin{abstract}
Encouraged by the uprisings in Tunisia and Egypt, and the Arab Spring, young Moroccans began to organise huge demonstrations across the country demanding more democracy, social justice and anti-corruption measures. The 20 February movement, named after the first demonstration held on that date in 20II, is a good illustration of one of the new social movements characterized by an intense use of technology and their diffuse membership. This article explores how protesters challenge the dominant institutions and norms in society through their struggle and how they try to create new meanings for these institutions, not only by protesting but also by using social media. We argue that using new social media is not only a vehicle for the mobilisation of activists, but also represents a form of new meaning-making for them: they participate, not only in a local sense, but also globally. Their online activities intersect and influence offline practices and vice versa, creating a continuous interaction which exerts an influence on both worlds. It is precisely this interconnectedness of offline and online worlds that is the decisive force in these movements and creates new meaning-making.
\end{abstract}

Key words: Morocco, Arab Spring, new social movement, social media, meaning-making

\section{Introduction}

This article explores the meaning of social media in the social uprisings during the 'Arab Spring' in Morocco, and the way activists in the 20 February movement, named after the first big demonstration held on that date in 20Ir, have used social media to mobilise the population and realise their goals. Communication and information technologies proved to be important means of informing and mobilising people in the Middle East to demonstrate against their political leaders. The use of the internet, mobile phones and Facebook has led to numerous scholarly discussions taking place about the value of social media and the political influence it has had on the rise and development of the socalled Arab Spring (Abbink 2012:4).

Various scholars and activists had high expectations of the potential of the internet and social media to 'democratize' society; the popular media called the protests in the Middle East a 'Twitter revolution' set up by the Facebook group generation (Khondker, 20II:677) and in authoritarian societies such as Morocco and Egypt, in particular, where freedom of speech was very restricted, Facebook became a vital platform for the exchange 
of a wide range of opinions in lively debates (Iskander, 20II:I226). These high expectations were also reflected in the wide use of the rather overly-optimistic term 'Arab Spring', referencing the Prague Spring in I968, the Czechoslovakian revolt against the Communist regime and the uprisings in other Eastern bloc countries calling for more democracy.

Not all scholars have adopted such a positive attitude towards the meaning of the new media in social movements in the Middle East. Lerner (2010:558), for instance, takes a very sceptical stance, arguing that the internet does not offer any solutions to the threats that social movements encounter. In the case of Iran, where the first blogger emerged in 200I, Lerner (2010:559) emphasized that weblogs and websites did not contribute at all to the democratisation of the country, because anti-democratic forces and the government also had access to information and communication technologies. According to Lerner (2010), offline activism, although bolstered by the internet, has been proven to have had the most success. Khondker (2011:677) confirms this view, pointing out that conventional media, such as satellite television, were crucial in broadcasting the Arab uprisings to a wider audience. Lamer (2012:4) also puts forward the important contribution that satellite television, such as Al-Jazeera made, in the Arab revolts; this, according to her, is often neglected in discussions on the role of new media in the Arab Spring. However, Lamer (2012:6) perceives satellite channels to be a form of 'new media', an umbrella term, covering ICTs and also mobile phones.

One problem with these different perspectives is that digital dualism or binary thinking is still implied in their frame of reference, taking the online and offline world as two separate or opposite entities, assuming that one domain is more decisive than the other (cf. Jurgenson 20II). We argue that online activities intersect and influence offline practices and vice versa, creating a continuous interaction which exerts an influence on both worlds. This research project focuses, in particular, on how these social media, as appropriated by young activists, do not simply contribute to the mobilisation of people for social protest, but that it is precisely this interconnectedness of the offline and online worlds that is the decisive force in these movements.

We hold an anthropological perspective on social movements, and as such this study focuses on the perception of the activists and their agency in making meaning in their struggle (cf. Salman \& Assies 2007; Kurzman 2008:5). Social media contribute to sustaining the force and power of social movements, but are they limited to a functional role spreading the discontent and mobilising people? Or are there other processes of meaningmaking involved in the use of social media? This article examines how protesters through their resistance challenge the dominant institutions and norms in society and how they try to create new meanings, not only by protesting in a 'traditional' way but also by using social media. In addition, we ask: how does the use of social media express new 'meaning making'? We argue that social media is not only a mobilisation vehicle for activists, but that it also represents a form of new meaning-making, the recognition of the activists' social participation in the global world. 
This article is based on ongoing research which is taking place on transnational relationships and the role of new media in both Morocco and the Netherlands (Bartels and Brouwer 2013). From September until mid November in 20II, during the month of May in 2012, and in 2013 Brouwer Bartels and the social scientist Rachid Toutouh of the National Institute of Statistics and Applied Economics (INSEA) conducted qualitative research on the 20 February movement. A triangulation of anthropological methods was applied, offline as well as online. We observed several demonstrations organized by the 20 February movement in Rabat and Temara, we interviewed different activists from the 20 February movement, a police chief of an impoverished district in Rabat, several university lecturers and a number of students (activists who defended the power of the king as well). We also read and followed numerous websites, weblogs and Facebook pages of groups and individuals and online newspapers. During this research, Facebook was also used as an important research method and, by becoming Facebook friends, we were able to communicate regularly with the activists. This research is not yet finished, although we have witnessed a specific period of the activities of the 20 February movement, the struggle is ongoing, although with far fewer demonstrations and on a smaller scale (Ottaway 20I2; El Hani 20I3).

These research questions stated above will be addressed in the next three sections. We first present relevant characteristics of the social political context of Morocco. Although the background information of the young population and the system of the state is not an adequate reason on its own to prompt the national protests, it is still a significant factor. We then discuss the different theoretical perspectives on social movements and how the use of social media has changed these movements. The practices and demonstrations of the 20 February movement and the way in which activists appropriated social media in their struggle for more democracy, social justice and freedom of speech is then demonstrated.

\section{Social political context of Morocco}

Currently Morocco has more than 32 million inhabitants, 20\% of whom are aged between fifteen and twenty four. It has the highest illiteracy rate of the surrounding Arab countries; in 2008 44\% of the population were illiterate (with a higher percentage of women than men and a higher per cent of rural dwellers than the urban population). State education is considered to be of a lower quality than the widely-spread private schools (African Development Bank 20II: 5). Morocco is a very poor country, $15 \%$ of the population live below subsistence level and young people lack stable employment. According to official figures, $15 \%$ of the population are unemployed, $60 \%$ of whom are graduates (Floris 2010:6). For several years these unemployed graduates have protested almost daily in front of the Parliament of Rabat, demanding steady jobs in the public sector (Bogaert \& Emperador 20II:242); they did not join the 20 February movement because of their more targeted goal. Nowadays, more than half of the population in Morocco live in cities, most of whom have migrated from rural areas where unemployment is high and working conditions poor. 
Morocco is a religious, Islamic state with a parliament and political parties. The king is the centre of power, religiously legitimized by his ancestral line back to the Prophet and as Commander of the Faithful, a position in which he symbolises the unity of the country (Maddy-Weitzman, 2012:9I). The king is also recognised as a powerful economic force; the royal family and the king take part in economic business all over the country, currently owning 30\% of Morocco's economy (Balleria 20II:I4-I5; Benchemsi 2012:66). Criticising the king or his powerful position is formally not allowed and anyone doing so risks a jail sentence. It also is one of the biggest taboos in the country.

Nevertheless Morocco is considered to be one of the most democratic Islamic states in the Arab world as it holds formal elections and its public press has a degree of freedom of expression. From time to time, however, independent media have been attacked; a few Moroccan bloggers were prosecuted in 2009 (Alaoui 2010) and the rapper Mouad Belghouat, seen as a spokesman of the 20 February movement, was sent to jail on 9 September 20II (Boukhari 20II). Another example of the repression was the arrest of the journalist Ali Anouzla (of the online newspaper Lakome) on 17 September 2013 who was released on bail after a national and international outcry over the following months (Monjib 20I4). In addition, the corruption rate evident in business, juridical courts and bureaucracy is still growing according to Transparency International's Perceptions Corruption Index (African Development Bank 20II; Benchemsi 20I2:67). The current state system, therefore, can be better characterised as 'authoritarian' rather than 'democratic'.

Morocco's deficient democratic character and its population's poverty notwithstanding, the emergence of satellite television, mobile telephones and information communication technology has been impressive and these developments have had a rapid influence on Moroccan society. In relation to television coverage, $97 \%$ of Moroccan households own a television which is switched on for almost the whole day. Morocco counts even more mobile numbers than citizens, which is not so strange in a country where many people have two telephones. In 20II, one in three households owned a computer and $39 \%$ had an internet connection (checkfacebook.com). Seven million Moroccans use the internet on a daily basis, which means that public places such as work, school or internet cafés, provide an important form of access to the internet connection. More than four million Moroccans are currently on Facebook (checkfacebook.com) and people are still eager to connect: meeting young people, even in the countryside, means being asked to become a friend on Facebook. Young people are particularly active on the internet and social media: $4 \mathrm{I} \%$ of all users are between the ages of eighteen and twenty four (Rahman 20I2:338). To conclude: young Moroccans are actively appropriating social media, but how is this related to the 20 February movement? First of all, some anthropological views on social movements are explored. 


\section{Social movements and the role of social media}

Social movements have been intensively studied by many disciplines, including political scientists, sociologists and anthropologists, all with their different angles and varying approaches (Klandermans \& Roggeband, 2007). The anthropologists Salman \& Assies (2007:215) perceive a social movement as 'a complex and multilayered phenomenon', which is 'an informal or more formalized group of people or small scale organizations aimed at social change.' The advantage of such a broad definition is that all kinds of different associations are included, from those active at a local level to those which operate on a much larger scale, as long as they challenge the dominant order. The disadvantage, however, is that this broad definition does not provide a satisfactory framework for further study of the more specific characteristics of social movements.

For that reason we have drawn on the work of anthropologist Kurzman (2008:5) who advocates using the concept of 'meaning-making' when making an anthropological analysis of social movements. He states that meaning is implied in every social action, which can be framed in moral terms, such as what is right and wrong, or in cognitive terms, asking what is true or false (ibidem). When studying social movements from an anthropological point of view, the focus is on the activists' agency to create meaningmaking, asking questions such as: how do they collectively contest dominant norms, symbols and institutions of society or, how do they dispute mainstream interpretations and create alternative views (ibidem: 6). Salman \& Assies (2007:208) also consider this concept of meaning-making to be at the 'stake of the social movements' actions'. This view closely corresponds to the questions we raised in our research into the 20 February movement, as the protesters questioned, among other things, the meaning of democracy in Moroccan constitutional monarchy demanding 'real' democracy, freedom of speech and the right to exert more influence on reforms and other significant policy decisions.

Starting from the perception of the participants of a social movement implies accepting that these participants have very different motives or reasons for joining a movement, and that, as a consequence, movements are not homogenously constituted. On the contrary, participants and spokespersons often have very heterogeneous backgrounds and objectives (Salman \& Assies 2007:230). Salman \& Assies (2007) draw a distinction between the various stages in the formation of a social movement, starting with its emergence, the formation of collective action, the mobilization phase (with its myths, heroes and events), and finally, the period that it is in conflict with the authorities and other opponents. These different phases can occur simultaneously so, for example, one could state that the mobilization of people is a never-ending continuous process, with a series of different opponents criticizing it, which, in turn, can lead to various criticisms and conflicts between the participants.

Following Kurzman's view of meaning-making, it is relevant to focus on the specific repertoire of movements, the social activities and actions that participants feel are appropriate and feasible to instigate and set up (Kurzman 2008:9). One of the practices of collective action is to organize demonstrations in which protesters declare their existence, presence, and the aims, goals and demands of the movement; it is actually a form of recognition of 
their protest, and also a way of mobilizing new people. In addition, Bogaert \& Emperador (20II:243) stressed the significance of demonstrations as a legitimate form of communication, and as a specific way of producing alternative knowledge or meaning-making for the public. This is especially important in situations where the deviant voice is not heard in mainstream media, as is often the case in Morocco. Consequently, it is vital to be aware of any current discourses which are about the content and context of the messages and the demands of the movement (Kurzman 2008:12; Salman \& Assies 2007:230).

In our research we focused on young, independent protesters in Rabat who told us that they had been discussing political issues at a secret space on Facebook and that the revolts in Tunisia and Egypt had given them hope. They wanted to be 'more than a Facebook generation', which indicated that Facebook is, at the very least, an important means of communication for them. But more importantly, they strived to get broader access to the public, acknowledging that, in a country with high rates of illiteracy, not everybody has easy access to the internet. Castells (1996) introduced the term 'network society', stressing the value of identity and social networks in collective action. He made a distinction between 'old' and 'new' social movements; old ones tend to be based on a traditional class conflict between labourers and managers in industrial societies, such as labour unions. New ones are comprised of various social groups, such as gender, ethnicity, religion, or nationalist groups striving for recognition of their identity and emancipation. Following this view we framed the 20 February movement as a 'new' rather than an 'old' movement, but their frequent use of social media must also be taken into account.

Modern technologies have become a particularly valuable means of communication in 'new' social movements, transforming time, space, meaning and media networks (Salman \& Assies 2007:227). These network-based new social movements have a specific structure, durability and aim, and are characterised by their diffuse, fluid and democratic membership. They are also highly decentralised and globalised in their orientation with a different leadership role or no leaders at all (Juris 20I2:26I). Some scholars have even introduced the term 'new, new' social movements, uniting similar global, economic and cultural dimensions, implying that activists could use old tactics such as the demonstrations organised by the old movements as well as new strategies facilitated by communication technologies (Feixa, Pereira \& Juris 2009:426). We do not agree with the use of the term 'new, new' movement. It offers little clarification, and we wonder how strict a division between old and new movements can be made.

Continuing our focus on the use of social media by social movements, it is helpful to examine the lively debate that is ongoing. Allagui and Kuebler (20II:I435), for example, spoke of a 'new genre of revolution' referring to Tunisia and Egypt, stressing the significance of social networks and their informational and organizational role. Communication and information are crucial elements in these networks, and in the context of an authoritarian state, these media have become vitally important for young people. Social media offer them a virtual space to communicate and express their thoughts with likeminded people, and to have discussions without the control of their parents or the state (Allagui \& Kuebler 20II:I436). This is especially significant in authoritarian states where 
citizens have little opportunity for open political discussion (cf. Lerner 2010:559). As Sreberny (20II) puts it, 'Facebook provides a space where silence and fear are broken and trust can be built, where social networks can turn political, and where home and diaspora can come together'. These social media are used not only to plan actions, to mobilize people to protest on the street (which increases offline activities), but also to inform the world of what is going on. And this seems essential: participating in a social movement, appropriating social media generates new meanings: it relocates the movement from a local, regional or national movement to one which is part of the global world, thereby uniting the local with the global.

If we realize how social media is also embedded in mainstream media, such as television, then the multiplier effect of social media becomes even more apparent. Members of social websites, for example, have taped videos of demonstrations on their mobile phone and forwarded these to their friends in their social networks; this same video can then be broadcast by a satellite television, such as Al Jazeera, and reach all those people who do not have access to the internet (Allagui \& Kuebler 20II:I436). This is then supported by other social media, such as blogs, networking sites or websites, all taking their part in the wider distribution of messages and revolutionary content. The internet connects like-minded people facilitating the organisation of actions, social protests and the mobilization of large numbers of people. Allagui and Kuebler (ibidem) concluded, therefore, that information technologies empowered the users of these media, as they can control them on their own. It is not a separation of on - and offline - or to use Jurgenson's term 'digital dualism' (20II) - but the interaction between the online and the offline domain, and its multiplier effect, which created real opportunities for these new types of social movements and raised them to a higher and broader level.

In the rest of this article we demonstrate, by reference to the 20 February movement in Morocco, how these social media reveal and contribute to the construction of new meanings, and the rejection of old ones. We examine how these in turn nourish other, wider-reaching media and how these social media contents display young peoples' ambition to be heard in the public domain.

\section{The 20 February movement}

Who were the activists of 20 February movement and how did they appropriate social media and use it to such advantage in their efforts to mobilize people and achieve their goals? In their online and offline activities, processes of meaning-making are incorporated by collectively contesting and challenging dominant structures and institutions in society, such as democracy and social justice.

Who was protesting?

Young people were discussing the uprisings in other Arab countries on Facebook. They were not formally allied to mainstream political parties, although they were later supported by one of the oldest Moroccan Human Rights Organisation (AMDH). Politics in Morocco is very closely associated with the older generation, with corruption and bu- 
reaucracy, behaviour which young activists opposed and distrusted enormously (Magharoui 20II: 687). For that reason they considered themselves to be independent protesters, demanding freedom, equality, real democracy, social justice and dignity, issues that are related to an international human rights discourse. With the introduction of these new international terms, they were demonstrating that they rejected the old meanings of mainstream politics, but at the same time were trying to get access to an international public debate. This was one of the big surprises; the so-called apathetic, politically unconscious youth seemed to have woken up (Balleria 20II:I5). The involvement of young people, who were not thought to be politically conscious or active, became a main feature of this new social movement.

However, it was not only independent youths, but people from the Berber movement, from different political parties, Marxist groups and labour unions who joined the movement, or supported the demonstrations. The Islamists of the Party of Justice and Development (PJD) did not participate in the 20 February movement, but the biggest Islamist group, the Justice and Charity group (al-Adl wa-Ihsan) of the late Sheikh Yassine, actually did. This officially forbidden organisation has a long tradition of criticizing the status of the king and condemning the corruption of the political system. Although their arguments are different, the claims of the 20 February movement were almost the same as those which had been raised by the Justice and Charity group for years (Ait-Dada and Van Schaik 20I2). At a demonstration in Temara, a city near Rabat, one of the veiled activists of this organisation explained the reasons for the protest to us, "look around, do you see the bad quality of the houses, people have no jobs, no income, there is no justice".

In the big demonstrations of the 20 February movement we saw Islamist groups, veiled women, bearded men walking with young modern people in tight jeans, short sleeveless blouses, and girls without veils. For most people it was a very strange, odd combination, as supporters of this Islamist organisation are, in so many ways, the opposite of the young people from 20 February movement. The Islamists of the movement of Justice and Charity were renowned for their well-organised, hierarchical structure, led by their charismatic leader Sheikh Yassine, who died I3 December 2012, whereas the 20 February movement can be characterised by its diffuseness and openness. Referring to the Justice and Charity movement, one independent activist explained to us, "they are very powerful, they can mobilise a lot of people very quickly, therefore people are scared of them." This activist said he had no problems with their participation, but not all young activists shared this opinion. A young female activist told us that she did not like their participation, she did not trust them, but she could not, of course, prevent their participation. As the scholars above have shown, the heterogeneity of the protesters can be seen to be an important feature of this new social movement.

\section{Online and offline activities}

Activists of the 20 February movement had decided to make a video in order to mobilise people for the first big demonstration on 20 February 20II. In this video they asked men and women, young and old, to explain why they wanted to raise their voice. After 
their first video was made, one of the young activists mentioned that another video was needed to reach a broader public: "to find new people who were willing to show their face on the camera was not easy", he recounted, as they had experienced a lot of criticism and counter demonstrations after the launch of the first. Young Royalists, for example, had spread a rumour on the internet saying that the 20 February movement was critical of the king, stimulating fear amongst the general public. Activists stressed that their struggle was not against the king, but against the bureaucratic and powerful groups of authorities around the king, the so-called makhzen. They stated, "the king is not the topic, he is not the issue for the 20 February movement".

The young people of the 20 February movement continued their struggle by setting up various digital platforms, Facebook pages and Twitter accounts, to inform people about their demands and the actions that they were planning to organize. For example, they started the website Mamfakinch, meaning 'we will not give up', to update people in Arabic and English about the news of the movement and the demonstrations, and to collect articles on the struggle. Diverse online news sites were set up in Arabic, French and English, sites that published critical articles on the government, disputing the corruption evident in dominant political and juridical institutions.

The first demonstration on 20 February 201 I became a huge success, people from across the nation took to the streets to raise their voices; fifty-three cities were affected, with a turn-out of about $\mathrm{I} 50,000$ to 200,000 protesters, a unique moment in Moroccan history (Maghraoui 20II:687). A young activist we spoke to described how surprised people were when the first demonstrations spread across the whole country. These demonstrations illustrated one of the characteristics of this new type of social movement: its decentralised character, with autonomous groups in every city, each using social media as an important means of communication in the movement. For instance, Casablanca, Tangier and Tetouan, each had its own group of activists, who mobilised people from their network and, using their dedicated Facebook pages, communicated with other local groups (Bennani-Chraibi \& Jeghllaly 20I; Brouwer 2013).

Another characteristic of this new movement was its lack of a central formal leader (Maghaoui 20II: 688). When we raised this issue at a meeting with activists of the 20 February movement, they emphasized their horizontal, non-hierarchical organisation. They organized weekly offline meetings - assemblées nationales - to discuss strategic issues or exchange experiences with local authorities. They tried to make democratic decisions by giving people ample opportunity to express their views and develop their arguments (El Hani, 2013). But, we wondered, how could they articulate their demands in an authoritarian context like Morocco if they had no access to public media such as television or newspapers? "We are left alone", concluded one independent activist. In a political context with no freedom of press or speech, social media, which enabled a message to be spread very quickly, gained more and more significance. All the activists we spoke to were heavy Facebook users, some had 3000 friends, and posted a message almost every day, or made a critical comment on an event, shared photos of a demonstration or created funny links just to relax. "It is an addiction", one of them explained. 
Demonstrations were still crucial elements in the repertoire of the 20 February movement, and one of the few means to voice their demands in public, especially in poor areas where people have no access to the internet. One activist, for instance, described how he prepared the demonstration on 23 October $201 \mathrm{I}$ in Rabat, which he organized with a small group of people. The movement had previously used mostly black and white paint for its boards. This time, he explained, the theme of the demonstration was to be expressed in colours. They bought red, green and blue paint to write slogans on the banners, such as, 'Boycott the elections of the $25^{\text {th }}$ of November'. One of their supporters, who could barely write his own name, according to our spokesperson, wanted to wear the national flag as a symbol of unity, emphasizing the fact that they were all Moroccans. During the final demonstration he walked in the front row with the flag wrapped around his body creating a photo that went out across the world's media.

\section{Contesting and struggling}

The 23 October 201 I demonstration, like a lot of demonstrations before, started peacefully but ended in a battle with the police. One activist told us he was beaten roughly on his fingers and had to go to the hospital with fifty other wounded protesters. Later, on his Facebook page, he expressed his anger at the brutal way the police had stopped a nonviolent demonstration. Another independent female activist, who explained that violence "was happening all the time" at their demonstrations, made a video of police brutality. This was not easy because, while she was recording, she was watching her friend being beaten up; this was "twice as hard," she explained. However, she was convinced that it was necessary to show the world what was happening. She uploaded the video to the website Moroccoforchange, which created a huge, multiplier effect. Explaining the power of the media, she said: "See it as a spring, more people see that video, and they tweet about it, they Facebook, share it with others, it gets momentum". After this online action, she received a lot of requests for offline interviews and invitations to attend international conferences, where she met other activists of the Arab Spring and exchanged ideas and shared experiences.

Thanks to these meetings, the 20 February movement also developed a wide range of international contacts and, when the Occupy Wall Street movement emerged, the activists wanted to express their solidarity with them. On I5 October 20II, the international day of solidarity with this movement, the 20 February movement planned a demonstration in the modern part of Rabat, at a well-known shopping centre (cf. Juris 20I2). When we arrived at the location we did not spot a demonstration, but we noticed a lot of police. After a phone call to one of the activists we learned that the police had forbidden the demonstration from taking place. An alternative plan was suggested, namely to organise a sit-in in front of the Parliament in the centre later that day. At the end of the afternoon a small group of mostly young people, holding up banners with the text 'We are the 99\%' protested in the city centre. This small demonstration lasted just half an hour, as the police arrived in huge numbers. We noticed that the number of police was greater than all the protesters put together; this time the police did not behave violently, they just showed their power, which was sufficient to break up the protesters very quickly. 
From the moment that the 20 February movement started to organise their protest, other opposition groups, such as the royalists, have accused them of 'separatism, anarchism, atheism or elitism'. One of the key activists in the 20 February movement in Rabat explained that these groups were trying to obstruct their protest: "authorities paid poor people to provoke protesters into a demonstration". Benchemsi (2012:58) also reported that, from May 201 I onward, the police had begun to use more violence and hire 'counter-demonstrators'. Referring to Salman \& Assies' notions on the opposition to a social movement, this was an important and continuous element which the 20 February movement had to deal with. The systematic resistance of anti-2o February groups, the socalled bataljis, militant royalists, made the lives of activists, and even their families, very difficult (cf. Bogaert 2013:I02). These royalists sought to sustain their power position by using a variety of different means. From the start of the movement they harassed activists, offline as well as online (cf. Maghraoui,20II). Activists stressed their experiences of aggressive intimidation, describing how they were attacked on the street by people they did not know or how their websites were hacked. Lots of rumours were spread about the movement, for instance, that they were 'anarchists' or 'homosexuals'. In fact, every action taken by the movement was met by a counter action. One key activist asserted, "I am not afraid, but I am scared for my family, that they will be hurt".

Although the participants of the 20 February movement had different backgrounds, they shared a common general goal; they fought for 'real' democracy, social justice, dignity and equality. Supported by uprisings in other Arab countries, the 20 February movement struggled online and offline for their goals. The online and offline activities fuelled each other and became completely embedded in this type of 'new' social movement. Young people, in particular, were contesting the old established meanings of democracy and asking for 'real' democracy, demanding a voice in the public debate, not just in Morocco but all over the world.

\section{Conclusion}

Looking at the three years that have passed since the first big demonstration of the 20 February movement in 20II, or since the massive protests in Tunisia or Egypt, we must conclude that the high expectations of the protestors have remained unfulfilled. The 20 February movement challenged the meaning of the democratic character of the country, but the state today is still organised in a very authoritarian manner. The activists claimed more social justice as part of an international human rights discourse, which, although it was heard internally, did not produce any remarkable results in a national context. So, what did the 20 February movement finally achieve and what was the role of social media?

Activists appropriated social media to communicate intensively with each other, to convey messages on the internet and to spread videos on the web. They used digital platforms to express their anger or frustration when they were beaten by the police at demonstrations or when other activists were arrested. In the context of an authoritarian regime, access to social media is a powerful means for a social movement, however, it 
was not strong enough to defeat authorities' violence and counteractions. Social media were fully incorporated in this 'new' social movement, (as we perceive the 20 February movement to be), intersecting the offline activities. This online involvement also implies, almost automatically, that this movement is mainly an urban in character and run mostly by young educated people; the high illiteracy and the lack of communication facilities in rural areas exclude those inhabitants from active participation.

As a consequence we rejected any strict separation between the online and offline world, and contested the digital dualism or binary thinking that scholars such as Lerner (20I0) or Khondker (20II) have applied.

More than three years after the first demonstration, the political situation in Morocco has changed dramatically. The 25 November 201 I elections were won by the Party of Justice and Development (PJD), which did not support the 20 February movement. The Islamists of the Justice and Charity group have withdrawn from the 20 February movement; its heterogeneity and diffuse membership, which was once its strength appears now to be its weakness. One of the consequences of this lack of cohesion and coherence was that a large number of diverse round table meetings and conferences have been organised across the country about the 'Moroccan Spring' in order to discuss new strategies for the future. Some groups decided to work henceforth on small concrete projects, which they assumed would be easier for most people to understand, such as resistance to the modern and expensive high speed train (TGV) planned for the west coast of Morocco for which they had launched a discussion page on Facebook to inform people about their actions.

Others tried to start international online networks to continue the political struggle. In the meantime they were trying to learn from their mistakes and elaborated innovative plans and, in various cities even set up new political parties and student organisations to discuss the problems in the education system. All these initiatives demonstrate that, although the 20 February movement is currently very weak, young independent activists are still involved in contesting old symbols, challenging traditional institutions and creating new views (cf. El Hani 20I3; Hoffman \& König 20I3: I8). In other words, they are engaged in processes of new meaning making, connecting the local with the global and, at the same time, developing their citizenship skills (Lamer 2012: I0). As several scholars explained, 'the ghost is out of the bottle', the current situation where people dare to raise their voice is 'irreversible'.

\section{References}

Abbink, J. (2012). Revolte en revolutie in de 'Arabische lente': duurzame politieke klimaatverandering? (Revolt and revolution in the 'Arab Spring": sustainable political climate change? (Talma lecture). Amsterdam Vrije Universiteit (retrieved November I3, 20I2,http://www.fsw.vu.nl/nl/Images/Talmalezing\%20I3\%20 januari\%202012_tcm30-252366.pdf).

African Development Bank. (20II). Tackling youth unemployment in the Maghreb (retrieved December I, 20II, http://www.Afdb.org.

Ait-Dada, A. \& van Schaik, R. (20I2). Political Islam and the Moroccan Arab Spring. Final Research Report. Minor Social Sciences. Rabat: Nederlands Instituut Marokko (NIMAR). 
Alaoui, A. (2012). Another blogger imprisoned. Global Voices. December I8 (retrieved February 23, 20I2). http://globalvoicesonline.org/2009/12/18/morocco-another-blogger-imprisoned/.

Allagui, I. \& Kuebler, J. (20II). The Arab Spring and the Role of ICTs. Editorial Introduction. International Journal of Communication 5: pp. I435-I442.

Balleria, M. (20II). Why now, what is next: The February 2oth movement challenge to the state. SIT Morocco and Multiculturalism and Human Rights. January 4. ISP Collection, paper 1003 (retrieved November 6 , 20II). http://digitalcollections.sit.edu/isp_collection/1003

Bartels, E. \& Brouwer, L. (2013). Islam, Democracy and New Media, a Moroccan Case Study. In: Risky Liaisons. Democracy and Religion. Reflections and Case Studies. G. Buys , T. Sunier \& P. Versteeg (eds). (pp.I96-217). Amsterdam: VU University Press.

Bartolucci, V. (20II). Moroccan Exception, and a King's speech. Open Democracy, April 6 (retrieved July 7, 20II). http://www.opendemocracy.net/valentina-bartolucci/moroccan-exception-and-kings-speech

Bennani-Chraibi, M. \& Jeghllaly, M. (2012). The Protest Dynamics of Casablanca's February 2oth Movement. Presses de Sciences Politiques 5(62): pp. I03-I30.

Benchemsi, A. (2012). Morocco: Outfoxing the Opposition. Journal of Democracy 23(I): pp. 57-69.

Bogaert, K. (2013). 20 Februari en de Marokkaanse klassenstrijd in de periferie. In: S. Zemni (ed.). Het MiddenOosten. The times are a-changin' (pp. 8I-I05). In samenwerking met Middle East en North Africa Research Group (MENARG), Universiteit Gent. Berchem: EPO.

Bogaert, K. \& Emperador, M. (20II). Imagining the State Through Social Protest: State Reformation and the Mobilizations of Unemployed Graduates in Morocco. Mediterranean Politics I6 (2): pp. 24I-259.

Boukhari, K. (20II). L7AgD, le rappeur des deux Oukacha. TelQuel. Octobre I7.

Brouwer, L. (2013). 'De video vertelt de waarheid'. Veldnotities. ZemZem. Tijdschrift over het Midden-Oosten, Noord-Afrika en islam I: pp. 78-85.

Castells, M. (1996). The Rise of the Network Society. The Information Age: Economy, Society and Culture. Cambridge, Oxford: Blackwell.

El Hani, N. (2013). "Activists do not fall from the Sky." The Globalization of on- and offline activism and Human Security within Rabat's 2o February Movement, Morocco. Master's Thesis Social and Cultural Anthropology. Amsterdam: VU University.

Feixa, C., Pereira, I. \& Juris, J. (2009). Global Citizenship and the 'New, New' Social Movements: Iberian Connections. Young I7 (4): pp. 42I-442.

Floris, S. (2010). Studies on Youth Politics in the Mediterranean partner countries. Morocco. Euromed. Euro-Med Youth Programme (retrieved December I, 20II). http://euromedyouth.net.

Herrera, L. (20II). Egypt's Revolution 2.0: The Facebook Factor. Jadaliyya. February I2 (retrieved May I3, 20I2). http://www.jadaliyya.com/pages/index/6r2/egypts-revolution-2.o_the-facebook-factor.

Hoffman, A. \& König, C. (2013). Scratching the Democratic Façade: Framing Strategies of the 20 February Movement. Mediterranean Politics I8(I): pp. I-22.

Jurgenson, N. (20II). Digital Dualism versus Augmented Reality. The Society papers (retrieved November IO, 20II). http://thesocietypages.org/cyborgology/201I/02/24/digital-dualism-versus-augmentedreality/.

Juris, J.S. (2012). Reflections on Occupy Everywhere: Social Media, Public Space, and Emerging Logics and of Aggregation. American Ethnologist 39(2): pp. 259-279.

Khondker, H.H. (20II). Role of the New Media in the Arab Spring. Globalizations 8(5): pp. 37-4I.

Klandermans, B. \& Roggeband, C. (eds.) (2007). A Handbook of Social Movements Across Disciplines. New York: Springer.

Kurzman, C. (2008). Introduction: Meaning-Making in Social Movements. Anthropological Quarterly 8I(I): pp. 5-15.

Lalami, L. (20II). Rocking the Casbah. Moroccan's day of dignity. The Nation (retrieved November 7, 20II). http://www.thenation.com/blog/15875I/rocking-casbah-moroccos-day-dignity\# 
Lamer, W. (2012). Twitter and Tyrants: New Media and its Effects on Sovereignity in the Middle East. Arab Media and Society I6: pp. I-22.

Lerner, M.Y. (2010). Connecting the actual with the virtual: the internet and social movement theory in the Muslim world - the cases of Iran and Egypt. Journal of Muslim Minority Affairs 30(4): pp. 555-574.

Monjib,M.(2014).AninterviewwithMoroccanJournalistAliAnouzla.SadaJournal 20February2014(retrieved March 25, 2014) http://carnegieendowment.org/sada/index.cfm?fa=show\&article=54582\&solr_ hilite $=$ Anouzla + Ali

Ottaway, M. (2012). Morocco: Can the Third Way Succeed? Carnegie Middle East Center. Arab Politics. Commentary. July 3I (retrieved November I2, 2012). http://m.ceip.org/2012/07/3I/morocco-can-thirdway-succeed/d 3 qu\&lang=en

Maddy-Weitzman, B. (20I2). Is Morocco Immune to Upheaval? Middle East Quarterly. Winter: pp. 87-93.

Maghraoui, D. (20II). Constitutional reforms in Morocco between consensus and subaltern politics. The Journal of North African Studies I6(4): pp. 679-699.

Rahman, Z. (2012). From Keyboard to Megaphone: Facebook and Moroccan Youth. In: F. Sadiqui (ed.) Femmes et Nouveaux Médias dans la Région Méditerranée (pp. 325-360). Fondation Hanns Seidel.

Salman, T. \& Assies, W. (2007). Anthropology and the Study of Social Movements. In: B. Klandermans and C. Roggeband (eds) A Handbook of Social Movements Across Disciplines. (pp. 20I-265). New York: Springer.

Sreberny, A. (2012). A social media revolution? Media and Social Change.net. May I2 (retrieved May I3, 2012). http://mediasocialchange.net/2011/05/12/a-social-media-revolution/ 